\title{
Seedling competition between native cottonwood and exotic saltcedar: implications for restoration
}

\author{
Joydeep Bhattacharjee $\cdot$ John P. Taylor Jr. • \\ Loren M. Smith · David A. Haukos
}

Received: 4 November 2007/Accepted: 24 September 2008/Published online: 15 October 2008

(C) The Author(s) 2008. This article is published with open access at Springerlink.com

\begin{abstract}
Altered hydrology of southwestern United States rivers has led to a decline in native cottonwood (Populus deltoides). Areas historically dominated by cottonwood have been replaced by invasive saltcedar (Tamarix chinensis). Restoration of historic hydrology through periodic flooding of riparian areas has been a means of restoring native species. However, due to similarity in germination requirements of cottonwoods and saltcedars, flooding may create an unwanted increase in the number of saltcedar seedlings. Therefore, we evaluated competitive aspects of these cooccurring species in an extant riparian habitat in the arid southwestern US. We measured effects of competition between cottonwood and saltcedar seedlings
\end{abstract}

The author J. P. Taylor is deceased.

J. Bhattacharjee $(\bowtie)$

Department of Biology, University of Louisiana

at Monroe, Monroe, LA 71209-0520, USA

e-mail: joydeep@ulm.edu

J. P. Taylor Jr.

Bosque del Apache National Wildlife Refuge,

P.O. Box 1246, Socorro, NM 87801, USA

L. M. Smith

Department of Zoology, Oklahoma State University, Stillwater, OK 74078, USA

D. A. Haukos

U.S. Fish and Wildlife Service, Department of Natural

Resources Management, Texas Tech University,

Lubbock, TX 79409-2125, USA and among cottonwood seedlings during the first growing season following seedling establishment in $360,0.5 \times 0.5-\mathrm{m}$ plots at the Bosque del Apache National Wildlife Refuge, New Mexico. We used five interspecific density treatments and five intraspecific density treatments. Cottonwood seedling biomass and height were twice that of saltcedar seedlings across all density treatments. As density of cottonwood increased, intraspecific competition increased in severity and biomass of cottonwood seedlings decreased. At 4 plants $/ 0.25 \mathrm{~m}^{2}$, cottonwood seedlings had the greatest biomass; whereas, survival was highest at 10 plants/ $0.25 \mathrm{~m}^{2}$. Our results support greenhouse studies and suggest that if favorable germination conditions are established for cottonwood in floodplains, saltcedar seedlings that cogerminate could be outcompeted by native cottonwood seedlings.

Keywords Biomass - Competition - Cottonwood · Saltcedar $\cdot$ Seedling $\cdot$ Riparian

\section{Introduction}

Competition is considered an important factor in structuring plant communities (e.g., Tilman 1988; Grime 2001). However, ecologists find it difficult to make accurate predictions about the outcome of competitive interactions in many plant communities (e.g., Connell 1983; Connor and Simberloff 1979; 
Gilpin and Diamond 1984). Most plant competition studies can broadly be divided into two categories; one that evaluates accumulation of resources (Tilman 1982; Grime 2001) and the other that measures the fitness and survivability (Silvertown and Charlesworth 2001). Studies have examined the effects of mean density on performance or yield in plant populations (deWit 1960; Norrington-Davies 1967; Schutz and Brim 1967). These approaches assume that an average density provides an effective description of the state of the population without considering variation among individuals (Pacala and Silander 1985). However, the fate of an individual plant is often contingent upon other plants in its immediate neighborhood (Pacala and Silander 1990; Tyler and D'Antonio 1995).

Research in the past two decades (e.g., Goldberg and Werner 1983; Pacala and Silander 1985; Stoll and Weiner 2000) has shown that size and density primarily determine the outcome of plant interactions, whereas, type of neighbor (species identity) matters less. This theory is reinforced by the idea that all plants require only a few resources (light, water, space, and nutrients), so species capable of acquiring these resources at a greater rate than others will eventually come out as the superior competitor. Interactions among plant species are therefore not strongly species specific (Goldberg and Landa 1991).

Because humans worldwide now use more than half ( $\sim 54 \%$ ) of the geographically and temporally accessible river runoff (Postel et al. 1996), it is not surprising that we have had a significant impact on the structure and functioning of riparian areas. Therefore, anthropogenic disturbance regimes influence the establishment (Stromberg et al. 1991; Scott et al. 1997), mortality (Schumm and Lichty 1963; Stromberg et al. 1997), and patch structure (Salo et al. 1986; Friedman et al. 1995) of riparian plant communities. Alteration of natural hydrologic regimes of most rivers in the southwestern US has led to degradation of riparian habitats. Most areas historically dominated by Rio Grande cottonwood (Populus deltoides Bartr. ex Marsh.) have been replaced by exotic saltcedar (Tamarix chinensis Lour.; Howe and Knopf 1991). Therefore, for successful restoration of such areas, it is often recommended to induce conditions that mimic the natural ecosystem processes (Attiwill 1994; Grumbine 1994; Hobbs and Norton 1996; Fule et al. 1997). In natural riparian areas, overbank flooding after spring snowmelt results in scouring the substrate, removing competing vegetation, and potentially creating "seed beds" for native vegetation to regenerate (Taylor et al. 1999; Bhattacharjee et al. 2006). Restoration often becomes difficult if exotics respond to natural disturbances by establishing as successfully as natives (Sprenger et al. 2002).

As potential competitors, cottonwood and saltcedar have similar requirements for germination (Horton et al. 1960), however, following recruitment, the two species have different growth dynamics with cottonwoods often growing more rapidly following germination (Merkel and Hopkins 1957; Horton et al. 1960; Fenner et al. 1984). Based on theories of plant competition, plants with higher growth rates should be competitively superior to plants with slower growth rates, because of greater resource access and utilization (Grime 1977; Goldberg and Landa 1991). Although growth of saltcedar is slow compared to cottonwood, current prevailing conditions in most semi-arid and arid altered floodplains have led to higher densities of saltcedar than native species. Therefore, to predict species dominance of future restored riparian communities, it is essential to evaluate the competitive abilities of cottonwood against varying densities of saltcedar under potential restoration conditions.

Due to high initial seedling densities in the field, especially for saltcedars $\left(>1,000\right.$ plants $/ \mathrm{m}^{2}$ vs. a high of about 15-20 plants $/ \mathrm{m}^{2}$ for cottonwoods, Bhattacharjee et al. 2006), intra- and interspecific competition at the seedling stage is important in determining the structure of the succeeding plant community (Segelquist et al. 1993; Stromberg 1997). Interspecific competition between cottonwood and saltcedar, and intraspecific competition within cottonwood, has been studied in greenhouse settings (Sher et al. 2000; Sher and Marshall 2003); results suggest that cottonwood dominates saltcedar at certain densities. However, there is a need to test the competitive outcome of the two species under natural field conditions. Therefore, we evaluated competitive ability of native cottonwood against invasive saltcedar in the Rio Grande floodplain under field conditions.

\section{Methods}

Our study was conducted in 12, 4 ha impoundments in the historic floodplain of the Rio Grande at the Bosque 
del Apache National Wildlife Refuge (BDANWR) $\left(33^{\circ} 48^{\prime \prime}, 106^{\circ} 53^{\prime \prime}\right)$, in central New Mexico, US. The active floodplain width was restricted to $1 \mathrm{~km}$ by a spoil levee built in the late 1950s on the west side of the river in conjunction with the construction of a low flow conveyance channel. Historically, flows of the Rio Grande River were characterized by an annual hydrograph typical of many river systems in western North America (Scott et al. 1993), with peak flows occurring in late May and June following snowmelt in upstream mountainous regions (Crawford et al. 1993). However, due to damming of the Rio Grande at several places, such flow regimes have been disrupted and the natural hydrology of the river has been altered (Taylor et al. 1999).

Average annual precipitation at the refuge is $21.9 \mathrm{~cm}$, with nearly $50 \%$ of the annual precipitation occurring during July, August, and September. Average daily maximum temperature from June through September is $23.6^{\circ} \mathrm{C}$ and average daily low temperature during this period is $13.3^{\circ} \mathrm{C}$ (Bhattacharjee et al. 2007).

Existing vegetation in the 12 impoundments was cleared using a bulldozer, 6 months prior to the start of the study. We established 30 plots $(0.5 \times 0.5-\mathrm{m})$ per impoundment to study seedling competition between cottonwood and saltcedar during spring 2002. Plots were independent experimental units. Of the 30 plots, we used 15 each to study intraspecific competition in cottonwoods and interspecific competition between cottonwood and saltcedar in each impoundment. To initiate germination of the two species, the impoundments were subjected to flooding and staged water drawdown (Bhattacharjee et al. 2006) timed with natural seed dispersal of the two species.

The experimental design was a response surface type in which the relative proportions and total density of the two species varied (Scheiner and Gurevitch 2001, p. 83). This considers potential interaction between density and species ratios, and has been recommended for competition studies between two species (Fairbank and Watkinson 1985; Connolly 1986; Gibson et al. 1999; Sher et al. 2000). Cottonwood to saltcedar ratios used in the interspecific study were 2:2, 2:4, 5:15, 10:20, and 15:25 plants $/ 0.25 \mathrm{~m}^{2}$. Plots were established when seedlings of both species could be identified. Plots for intraspecific competition in cottonwoods contained 4, 10, 20, 30, and 40 plants/ $0.25 \mathrm{~m}^{2}$. These densities were based on observations of natural plant communities in the area and previous studies (Taylor et al. 1999; Sprenger et al. 2002; Bhattacharjee et al. 2006). To achieve the above densities, we selected areas that closely matched the required plant composition and established plots with sufficient plants of each species. If a plot had more plants than required for a specific treatment, we randomly selected plants within the plot and removed them until the plot contained the desired density and composition.

\section{Biomass estimation}

During October 2002, at the end of the first growing season, we used a nondestructive method of biomass estimation to predict seedling biomass in the plots. To estimate biomass, first we randomly selected and clipped 80 seedlings each of cottonwood and saltcedar from areas adjacent to, but outside study plots. These plants were representative of those in the plots because they recruited at the same time and under similar abiotic and biotic conditions as plants in the plots. For all clipped cottonwood seedlings, we measured height $(\mathrm{cm})$, number of leaves, width of the largest leaf $(\mathrm{cm})$, and basal diameter $(\mathrm{cm})$. For saltcedar seedlings, we measured height $(\mathrm{cm})$, number of branches on the longest stem, sum of lengths of all the branches $(\mathrm{cm})$, and basal diameter of the plant $(\mathrm{cm})$. Then, we used these measurements to develop linear regression models to predict biomass $(\mathrm{g})$ of plants in the plots. The same set of measurements was taken simultaneously for all plants in the plots. In addition to biomass as an indicator of competition, we also tested differences in plant height as a response regulated by competition (Sher et al. 2000; Sher and Marshall 2003). The regression model supported by the data for cottonwood seedling biomass was:

$$
\begin{aligned}
\text { Biomass cottonwood }= & -2.34+0.04 \text { (height) } \\
& +0.03 \text { (number of leaves) } \\
& +4.36 \text { (width of the largest leaf) } \\
& +0.11 \text { (basal diameter) } \\
& \left(R^{2}=0.88\right)
\end{aligned}
$$

However, as some of the plants had no leaves, we fit another model to estimate biomass of seedlings with no leaves: 


$$
\begin{aligned}
\text { Biomass }_{\text {cottonwood(leafless) }}= & -0.84 \\
& +2.25(\text { basal diameter }) \\
& +0.03 \text { (height }),\left(R^{2}=0.80\right) .
\end{aligned}
$$

The model used to predict biomass of saltcedar seedlings was:

$$
\begin{aligned}
\text { Biomass }_{\text {saltcedar }}= & -3.63+0.03 \text { (height }) \\
& +0.06(\text { number of branches on the } \\
& \text { longest stem })+7.48 \text { (basaldiameter }) \\
& +0.02(\text { sum of the lengths } \\
& \text { of all the branches in the plant }), \\
& \left(R^{2}=0.78\right) .
\end{aligned}
$$

\section{Data analysis}

Interspecific competition

We used Akaike's Information Criterion (AIC, Burnham and Anderson 2002) to select models that best explained the outcome of interspecific competition (measured as aboveground biomass and height) between cottonwoods and saltcedars. The difference in AIC values between each model and the model with lowest AIC was calculated and denoted by $\triangle$ AIC. We used a generalized linear model (GENMOD procedure in $\mathrm{SAS}^{\circledR}$ 2001) based on a maximum likelihood (Agresti 1990) to develop models. Potential predictive models for biomass estimation were developed based on the criterion $\Delta \mathrm{AIC} \leq 2$ for selecting models (Burnham and Anderson 2002) as this allowed selection of models that had the highest model weights $\left(W_{i}\right)$.

Overall, we tested 17 multiple-regression models (10 were developed by us and the remaining were developed in other studies) to predict height and biomass across different density treatments. We also included six models (five linear and one non-linear) developed by Sher et al. (2000) and Sher and Marshall (2003). Of the six, only one model (linear, for predicting the height and biomass of the two species) qualified to enter the model averaging process. The nonlinear models (model \# 16 and 17) to predict biomass and height of saltcedar seedlings by Shinozaki and Kira (1956) and Sher et al. (2000) did not meet the criterion we used to select models.
To evaluate the competitive relationship between the two species we used response surface analysis.

Once models were selected (using the AIC) we then graphed them as three-dimensional response surfaces, predicting biomass and height of the two species. Further, to examine how height and biomass of each species responded to the overall stem density (combined density of both species), we used a twoway ANOVA. In this analysis, we used the combined stem densities as the independent variable and height and biomass as dependent variables.

Intraspecific competition

We used a one-way analysis of variance (ANOVA) to evaluate overall differences in mean biomass per cottonwood seedling across the different intraspecific density treatments. Only plots with at least one live plant were used in the analyses. We did this to avoid including plots with no plants (plots without any plants would appear in the analyses as having no competition, which might not be the case). To evaluate survival, we used a one-way ANOVA (PROC GENMOD, SAS 9.1), where species densities were the independent variables and percent seedling survival was the dependent variable. We used all plots to determine seedling survival.

\section{Results}

Interspecific competition

Of the 17 models tested (15 linear and 2 nonlinear), four (model \# 8, 9, 11, and 13; Table 1) were averaged (based on $\triangle \mathrm{AIC} \leq 2$ ) to predict biomass and height of cottonwood seedlings (Table 2). For saltcedar, we averaged four models (model \# 9, 11, 13, and 15; Table 1) to predict seedling biomass (Table 3), but averaged five (model \# 8, 9, 11, 12, and 13; Table 1) to predict height (Table 4). In the models used to predict cottonwood biomass and height, saltcedar had low parameter estimates $(0.0342$ and 0.0845 , respectively, Table 4) indicating little influence of saltcedar density on either biomass or height of cottonwood seedlings. The parameter estimates of the model for predicting saltcedar biomass (Table 4), suggest cottonwood density had relatively greater $(0.0387)$ influence in determining 
Table 1 Models tested for varying seedling densities $(X)$ of cottonwood $(i)$ and saltcedar $(j)$, with the response variable $(Y$, density or height of either species) in the Bosque del Apache National Wildlife Refuge, New Mexico, 2002

\begin{tabular}{|c|c|c|c|c|c|c|}
\hline \multirow{2}{*}{\multicolumn{2}{|c|}{ Model }} & \multicolumn{2}{|c|}{ Cottonwood } & \multicolumn{2}{|l|}{ Saltcedar } & \multirow[t]{2}{*}{ References } \\
\hline & & $\begin{array}{l}\Delta \text { AIC } \\
\text { (Biomass) }\end{array}$ & $\begin{array}{l}\Delta \text { AIC } \\
\text { (Height) }\end{array}$ & $\begin{array}{l}\Delta \text { AIC } \\
\text { (Biomass) }\end{array}$ & $\begin{array}{l}\Delta \text { AIC } \\
\text { (Height) }\end{array}$ & \\
\hline \multicolumn{7}{|c|}{ Linear } \\
\hline 1 & $Y_{i}=\beta_{0}+\beta_{1}\left(X_{j}\right)+\beta_{2}\left(X_{i}\right)$ & 15.7 & 17.9 & 17.6 & 12.5 & Sher et al. (2000) \\
\hline 2 & $Y_{i}=\beta_{0}+\beta_{1}\left(X_{j}\right)+\beta_{2}\left(X_{i}+1\right)^{-1 / 2}$ & 7.1 & 6.3 & 6.5 & 6.0 & This study \\
\hline 3 & $Y_{i}=\beta_{0}+\beta_{1}\left(X_{j}\right)+\beta_{2}\left(X_{i}+1\right)^{-1}$ & 7.5 & 7.3 & 6.3 & 5.6 & This study \\
\hline 4 & $Y_{i}=\beta_{0}+\beta_{1}\left(X_{j}\right)+\beta_{2}\left(X_{i}+1\right)^{-3 / 4}$ & 7.5 & 6.8 & 6.4 & 5.9 & Sher et al. (2000) \\
\hline 5 & $Y_{i}=\beta_{0}+\beta_{1}\left(X_{j}\right)+\beta_{2}\left(X_{i}\right)^{-1}$ & 22.7 & 24.3 & 7.9 & 6.5 & Sher et al. (2000) \\
\hline 6 & $Y_{i}=\beta_{0}+\beta_{1}\left(X_{j}\right)+\beta_{2}\left(X_{i}\right)^{-3 / 4}$ & 8.8 & 9.4 & 7.5 & 6.6 & This study \\
\hline 7 & $Y_{i}=\beta_{0}+\beta_{1}\left(X_{j}\right)+\beta_{2}\left(X_{i}\right)^{2}$ & 8.6 & 8.7 & 40.4 & 15.3 & This study \\
\hline 8 & $Y_{i}=\beta_{0}+\beta_{1}\left(X_{j}\right)+\beta_{2}\left(X_{i}+1\right)^{-1 / 2}+\beta_{3}\left(X_{i}+1\right)^{-1}$ & 1.5 & 1.4 & 2.6 & 1.5 & This study \\
\hline 9 & $Y_{i}=\beta_{0}+\beta_{1}\left(X_{j}\right)+\beta_{2}\left(X_{i}+1\right)^{-1 / 2}+\beta_{3}\left(X_{i}+1\right)^{-3 / 4}$ & 0.4 & 0.4 & 1.4 & 0.4 & This study \\
\hline 10 & $Y_{i}=\beta_{0}+\beta_{1}\left(X_{j}\right)+\beta_{2}\left(X_{i}+1\right)^{-1 / 2}+\beta_{3}\left(X_{i}\right)^{-1}$ & 18.2 & 18.1 & 4.8 & 3.8 & Sher et al. (2000) \\
\hline 11 & $Y_{i}=\beta_{0}+\beta_{1}\left(X_{j}\right)+\beta_{2}\left(X_{i}+1\right)^{-1}+\beta_{3}\left(X_{i}+1\right)^{-3 / 4}$ & 0.0 & 0.0 & 1.1 & 0.1 & This study \\
\hline 12 & $Y_{i}=\beta_{0}+\beta_{1}\left(X_{j}\right)+\beta_{2}\left(X_{i}+1\right)^{-1}+\beta_{3}(X i+1)^{-1}$ & 17.7 & 17.6 & 3.1 & 2.0 & This study \\
\hline 13 & $Y_{i}=\beta_{0}+\beta_{1}\left(X_{j}\right)+\beta_{2}\left(X_{i}+1\right)^{-1}+\beta_{3}\left(X_{i}\right)^{-3 / 4}$ & 1.7 & 1.7 & 1.2 & 0.0 & Sher et al. (2000) \\
\hline 14 & $Y_{i}=\beta_{0}+\beta_{1}\left(X_{j}\right)+\beta_{2}\left(X_{i}+1\right)^{-3 / 4}+\beta_{3}\left(X_{i}\right)^{-1}$ & 18.0 & 18.0 & 4.2 & 3.1 & This study \\
\hline 15 & $Y_{i}=\beta_{0}+\beta_{1}\left(X_{j}\right)+\beta_{2}\left(X_{i}\right)+\beta_{3}\left(X_{i}\right)^{2}$ & 12.4 & 12.4 & 0.0 & 18.7 & This study \\
\hline \multicolumn{7}{|c|}{ Non-linear } \\
\hline 16 & $Y_{i}=W_{i} /\left[1+C_{i}\left(X_{i}+A_{i j} X_{j}\right)\right]$ & & $108.0^{\mathrm{a}}$ & $9,070.5^{\mathrm{a}}$ & $1,717.2^{\mathrm{a}}$ & $\begin{array}{r}\text { Shinozaki and } \\
\text { Kira (1956) }\end{array}$ \\
\hline 17 & $Y_{i}=X_{i} W_{i} /\left[1+C_{i}\left(X_{i}+A_{i j} X_{j}\right)\right]$ & & $179.5^{\mathrm{a}}$ & $10,077.9^{\mathrm{a}}$ & $1,723.8^{\mathrm{a}}$ & Sher et al. (2000) \\
\hline
\end{tabular}

Note: $\beta_{1,} \beta_{2}$, and $\beta_{3}$ are density coefficients and $C, A$, and $W$ are competition coefficients

${ }^{a}$ Model $\Delta$ AIC values were high and models were considered as bad fit

Table 2 Average model (based on the four selected models) for predicting biomass $(\mathrm{g})$ and height $(\mathrm{cm})$ of cottonwood $(\mathrm{cw})$ seedlings responding to interspecific competition between cottonwood and saltcedar (sc) seedlings at Bosque del Apache National Wildlife Refuge, New Mexico, 2002

\begin{tabular}{|c|c|c|c|c|c|c|c|c|}
\hline \multirow[t]{2}{*}{ Model } & \multicolumn{3}{|c|}{ Cottonwood } & \multirow{2}{*}{$\begin{array}{l}\mathrm{sc} \\
\beta \mathrm{i}\end{array}$} & \multirow{2}{*}{$\begin{array}{l}(\mathrm{cw}+1)^{-0.5} \\
\beta \text { iii }\end{array}$} & \multirow{2}{*}{$\begin{array}{l}(\mathrm{cw}+1)^{-1} \\
\beta \mathrm{iv}\end{array}$} & \multirow{2}{*}{$\begin{array}{l}(\mathrm{cw}+1)^{-0.75} \\
\beta \mathrm{v}\end{array}$} & \multirow{2}{*}{$\begin{array}{l}\mathrm{cw}^{-1} \\
\beta \mathrm{vii}\end{array}$} \\
\hline & AIC & Akaike's Wi & $\beta_{0}$ & & & & & \\
\hline 1 & 427.4 & 0.167 & 1.002 & 0.010 & 5.007 & -4.008 & $*$ & $*$ \\
\hline 2 & 426.3 & 0.290 & 0.762 & 0.011 & 8.203 & $*$ & -6.711 & $*$ \\
\hline 3 & 425.9 & 0.354 & 1.379 & 0.080 & $*$ & -10.28 & 10.509 & $*$ \\
\hline 4 & 427.6 & 0.151 & 2.060 & -0.001 & $*$ & 8.208 & $*$ & -4.418 \\
\hline \multicolumn{3}{|c|}{ Averaged model (biomass) } & 1.235 & 0.034 & 3.340 & -3.188 & 1.845 & -4.418 \\
\hline 1 & 489.4 & 0.181 & 5.909 & -0.088 & -4.512 & -0.145 & $*$ & $*$ \\
\hline 2 & 488.4 & 0.299 & 5.898 & -0.082 & -4.387 & 0.255 & $*$ & $*$ \\
\hline 3 & 488.0 & 0.365 & 5.573 & -0.087 & $*$ & 5.541 & -9.508 & $*$ \\
\hline 4 & 489.7 & 0.156 & 4.968 & -0.079 & $*$ & -11.313 & $*$ & 4.06 \\
\hline \multicolumn{3}{|c|}{ Averaged model (height) } & 5.636 & -0.085 & -2.127 & 0.307 & -9.508 & 4.06 \\
\hline
\end{tabular}

* Indicates that the variable was not included in the model 
Table 3 Average model (based on the four selected models) for predicting biomass $(\mathrm{g})$ and height $(\mathrm{cm})$ of saltcedar $(\mathrm{sc})$ seedlings, in interspecific competition between cottonwood

\begin{tabular}{|c|c|c|c|c|c|c|c|c|c|c|c|}
\hline \multirow[t]{2}{*}{ Model } & \multicolumn{3}{|c|}{ Saltcedar } & \multirow{2}{*}{$\begin{array}{l}\mathrm{cw} \\
\beta \mathrm{i}\end{array}$} & \multirow{2}{*}{$\begin{array}{l}\mathrm{sc} \\
\beta \mathrm{ii}\end{array}$} & \multirow{2}{*}{$\begin{array}{l}(\mathrm{sc}+1)^{-0.5} \\
\beta \mathrm{iii}\end{array}$} & \multirow{2}{*}{$\begin{array}{l}(\mathrm{sc}+1)^{-1} \\
\beta \mathrm{iv}\end{array}$} & \multirow{2}{*}{$\begin{array}{l}(\mathrm{sc}+1)^{-0.75} \\
\beta \mathrm{v}\end{array}$} & \multirow{2}{*}{$\begin{array}{l}\mathrm{sc}^{-1} \\
\beta \mathrm{vi}\end{array}$} & \multirow{2}{*}{$\begin{array}{l}\mathrm{sc}^{-0.75} \\
\beta \mathrm{vii}\end{array}$} & \multirow{2}{*}{$\begin{array}{l}\mathrm{sc}^{2} \\
\beta \text { viii }\end{array}$} \\
\hline & AIC & Akaike's Wi & $\beta \mathrm{o}$ & & & & & & & & \\
\hline 1 & $1,578.7$ & 0.189 & 2.440 & -0.057 & $*$ & -0.780 & $*$ & -0.580 & $*$ & $*$ & $*$ \\
\hline 2 & $1,578.4$ & 0.220 & 2.386 & -0.057 & $*$ & $*$ & 0.890 & -2.159 & $*$ & * & $*$ \\
\hline 3 & $1,578.5$ & 0.209 & 2.228 & -0.054 & $*$ & $*$ & 3.542 & $*$ & 1.134 & $*$ & $*$ \\
\hline 4 & $1,577.3$ & 0.381 & 1.087 & 0.192 & 0.114 & $*$ & $*$ & $*$ & $*$ & -0.009 & $*$ \\
\hline \multicolumn{3}{|c|}{ Averaged model (biomass) } & 1.868 & 0.0387 & 0.114 & -0.780 & -0.546 & -0.585 & 1.134 & -0.009 & $*$ \\
\hline 1 & $2,057.0$ & 0.131 & 1.980 & -0.006 & & 0.088 & 0.245 & $*$ & $*$ & $*$ & $*$ \\
\hline 2 & $2,055.9$ & 0.227 & 1.996 & -0.006 & & -0.127 & $*$ & 0.434 & $*$ & $*$ & $*$ \\
\hline 3 & $2,055.6$ & 0.264 & 1.986 & -0.006 & & $*$ & 0.133 & 0.188 & $*$ & $*$ & $*$ \\
\hline 4 & $2,057.5$ & 0.102 & 1.988 & -0.005 & & $*$ & 0.668 & $*$ & $*$ & $*$ & -0.201 \\
\hline 5 & $2,055.5$ & 0.277 & 2.015 & -0.006 & & $*$ & 1.738 & $*$ & -0.818 & $*$ & $*$ \\
\hline \multicolumn{4}{|c|}{ Averaged model (height) } & -0.006 & 1.996 & -0.017 & 0.616 & 0.148 & -0.818 & $*$ & -0.201 \\
\hline
\end{tabular}

* Indicates that the variable was not included in the model

Table 4 Final models for predicting individual plant biomass $(\mathrm{g})$ and height $(\mathrm{cm})$ for each species, where $X$ is the density of species $i$ (cottonwood) and $j$ (saltcedar) at the Bosque del Apache National Wildlife Refuge, New Mexico, 2002

\begin{tabular}{|c|c|c|}
\hline Species & Variable & Final averaged model \\
\hline \multirow[t]{2}{*}{ Cottonwood } & Biomass & $\begin{aligned} Y_{i}= & 1.2346+0.0342\left(X_{j}\right)+3.3404\left(X_{i}+1\right)^{-1 / 2} \\
& -3.1882\left(X_{i}+1\right)^{-3 / 4}-4.4183\left(X_{i}\right)^{-1 / 2}\end{aligned}$ \\
\hline & Height & $\begin{aligned} Y_{i}= & 5.6363-0.0845\left(X_{j}\right)-2.1265\left(X_{i}+1\right)^{-1 / 2} \\
& +0.3071\left(X_{i}+1\right)^{-1}-9.5079\left(X_{i}+1\right)^{-3 / 4}+4.06\left(X_{i}\right)^{-1}\end{aligned}$ \\
\hline \multirow[t]{2}{*}{ Saltcedar } & Biomass & $\begin{aligned} Y_{j}= & 1.8678+0.0387\left(X_{i}\right)+0.1144\left(X_{j}\right)-0.7796\left(X_{j}+1\right)^{-1 / 2} \\
& -0.5455\left(X_{j}+1\right)^{-1}-0.5847\left(X_{j}+1\right)^{-3 / 4}+1.1341\left(X_{j}\right)^{-1} \\
& -0.0088\left(X_{j}\right)^{-3 / 4}\end{aligned}$ \\
\hline & Height & $\begin{aligned} Y_{j}= & 1.9955-0.0057\left(X_{i}\right)-0.0172\left(X_{j}+1\right)^{-1 / 2} \\
& +0.6163\left(X_{j}+1\right)^{-1}+0.1480\left(X_{j}+1\right)^{-3 / 4} \\
& -0.2012\left(X_{j}\right)^{2}-0.8175\left(X_{j}\right)^{-1}\end{aligned}$ \\
\hline
\end{tabular}

biomass of saltcedar; reducing saltcedar biomass at higher densities.

Response surface analysis

Increases in saltcedar density from 0 to 25 plants/ $0.25 \mathrm{~m}^{2}$ had no negative impact on biomass of cottonwood seedlings (Fig. 1a). Even at a cottonwood-saltcedar ratio of 3:5, biomass of cottonwood seedlings was not affected by competing saltcedar seedlings. Height of cottonwood seedlings, on the other hand was greatest at moderate densities of cottonwood and saltcedar (a mixed density of about 9-12 cottonwood seedlings and 10-15 saltcedar seedlings) (Fig. 1b). (cw) and saltcedar seedlings at Bosque del Apache National Wildlife Refuge, New Mexico, 2002 

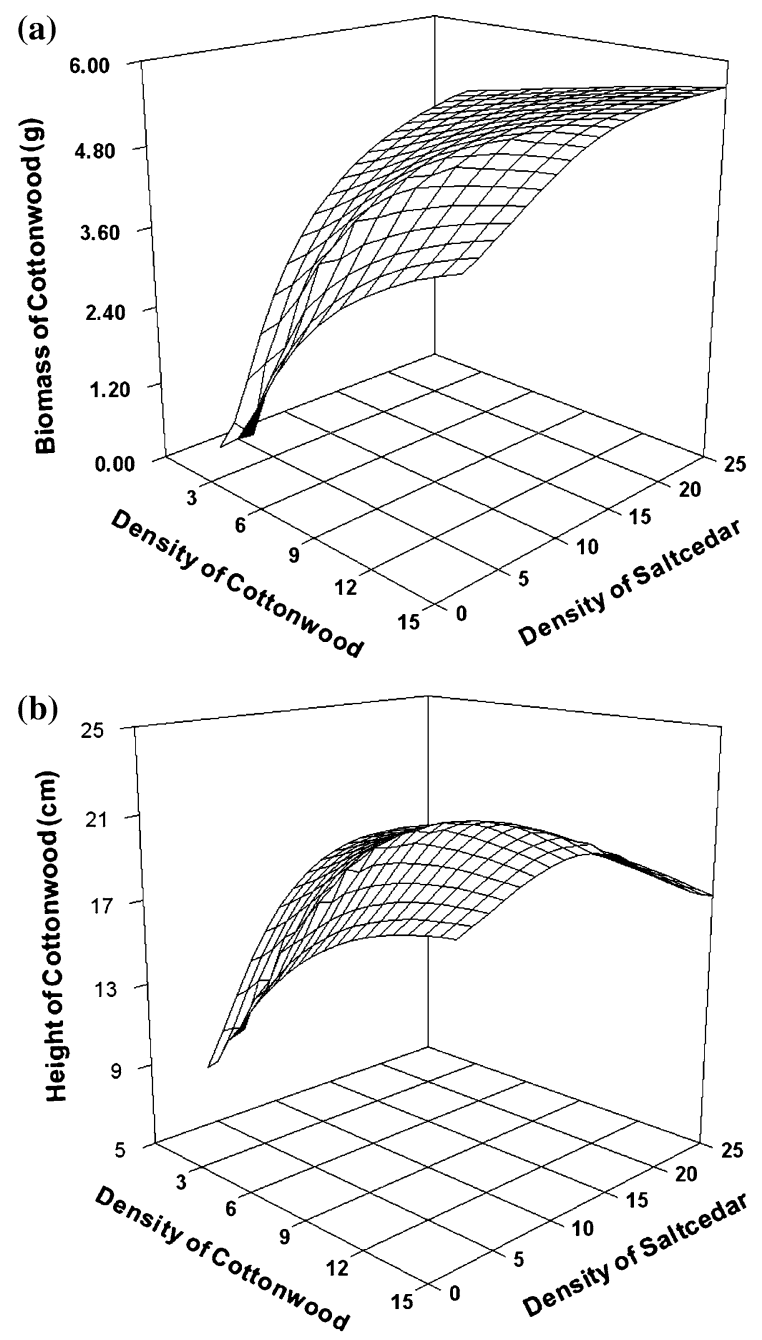

Fig. 1 Modeled biomass (a) and height (b) for cottonwood seedlings in interspecific competition experiment conducted at the Bosque del Apache National Wildlife Refuge, New Mexico, 2002. Densities represent number of plants per $0.25 \mathrm{~m}^{2}$ plot

(Fig. 3). When the combined density of the two species was below 20 stems $/ 0.25 \mathrm{~m}^{2}$, cottonwood seedlings had greater biomass than at higher (30-40 stems $/ 0.25 \mathrm{~m}^{2}$ ) stem densities (Fig. 3). Cottonwood seedlings were taller when the combined density of the two species in the area was below 30 stems/ $0.25 \mathrm{~m}^{2}$. Height of cottonwood seedlings showed a trend similar to biomass, with greater heights at lower combined stem densities $\left(F_{4,249}=3.71, P=0.006\right)$. Stem densities between 6 and 30 stems $/ 0.25 \mathrm{~m}^{2}$ resulted in the greatest biomass of saltcedar seedlings. Saltcedar seedling biomass was low at both
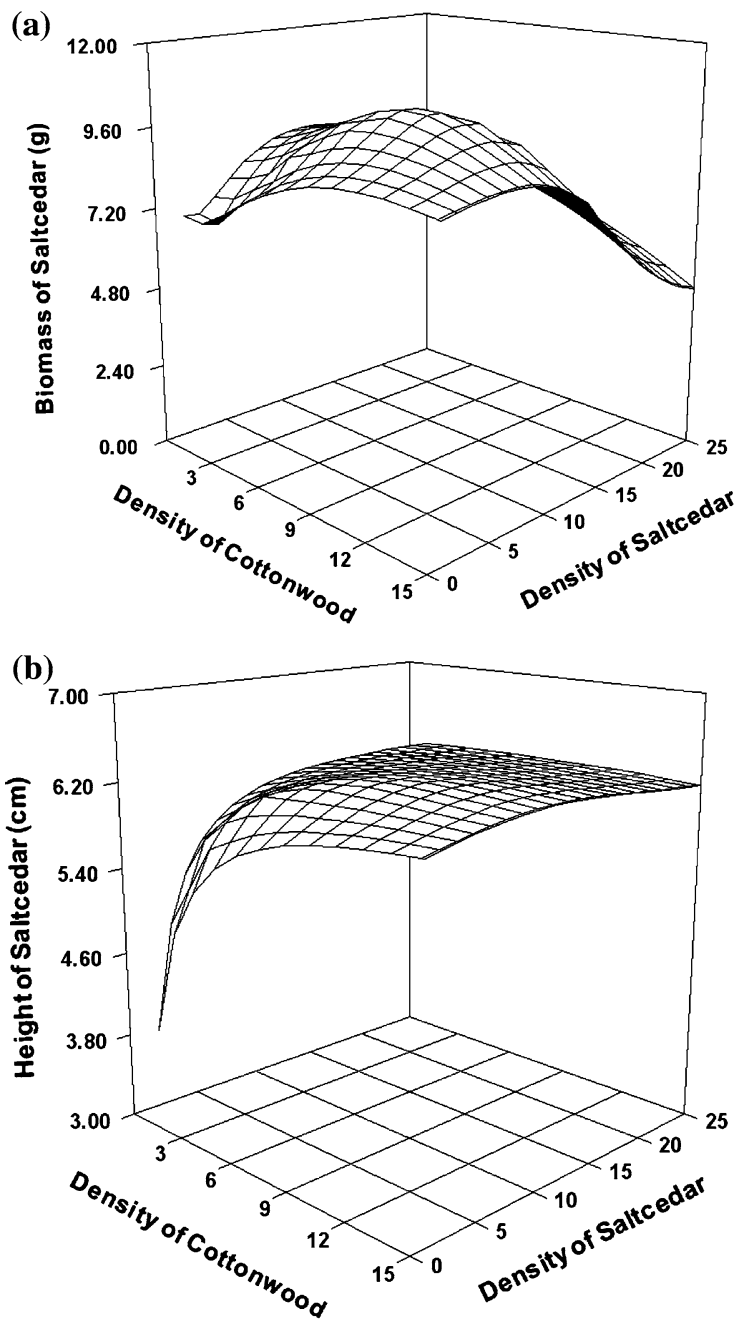

Fig. 2 Modeled biomass (a) and height (b) for saltcedar seedlings in interspecific competition experiment conducted at the Bosque del Apache National Wildlife Refuge, New Mexico, 2002. Densities represent number of plants per $0.25 \mathrm{~m}^{2}$ plot

extremes of density treatments. Height of saltcedar did not exhibit any distinct trend (Fig. 3). However, the mean biomass of cottonwood seedlings across all treatments was twice that of saltcedar (Fig. 3). In addition, cottonwood seedlings were more than twice as tall and as heavy (biomass) as saltcedar seedlings by end of the first growing season.

Intraspecific competition

Biomass of cottonwood seedlings differed among density treatments $\left(F_{4,105}=4.42, P=0.002\right)$. Individual seedling biomass was greatest $(\bar{x}=15.60 \mathrm{~g}$, 
Fig. 3 Mean biomass and height for saltcedar and cottonwood seedlings in interspecific competition experiment conducted at the Bosque del Apache National Wildlife Refuge, New Mexico, 2002. Means followed by different lowercase letters are different $(P<0.1)$ among treatment ratios. Error bars represent standard error
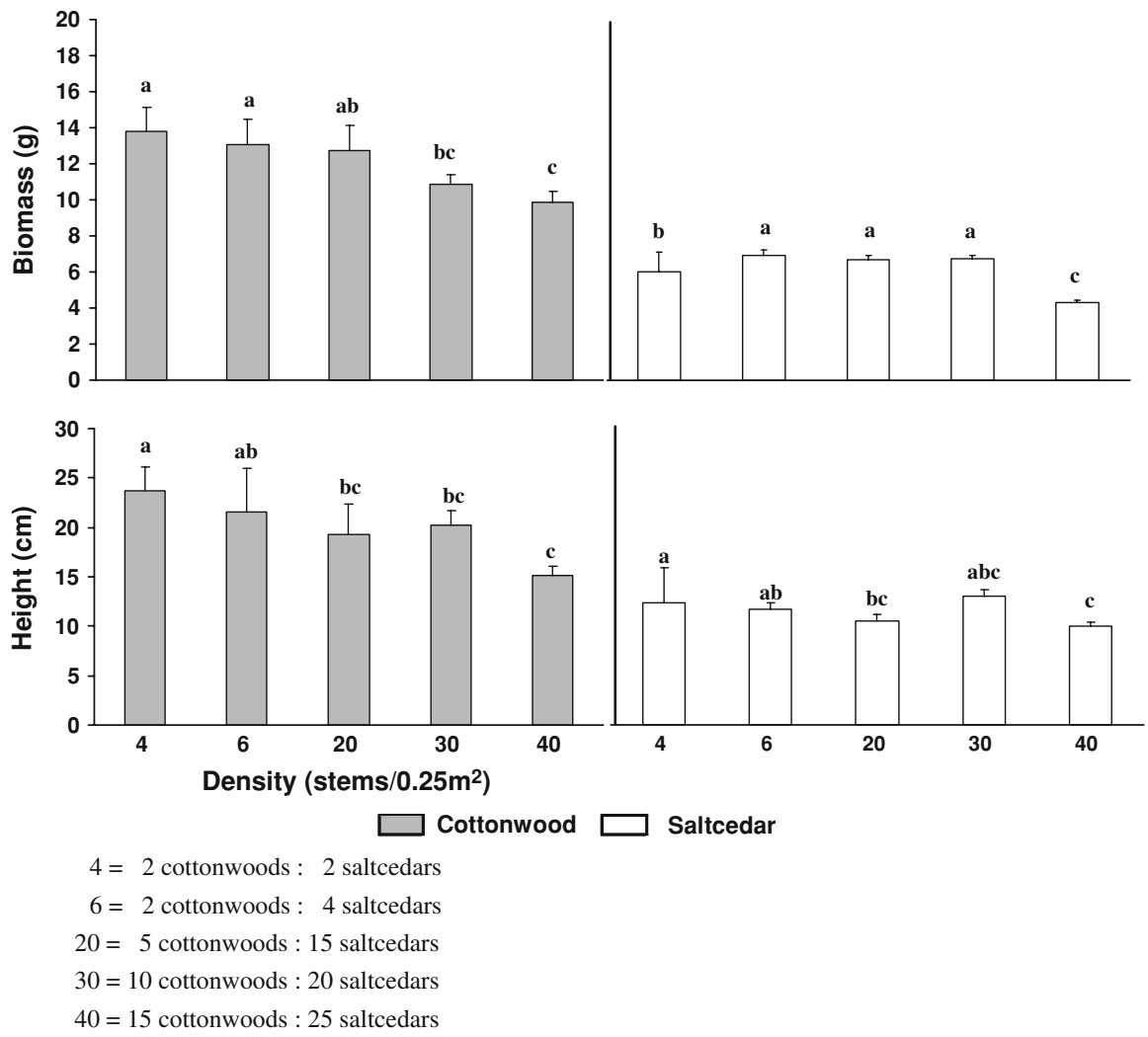

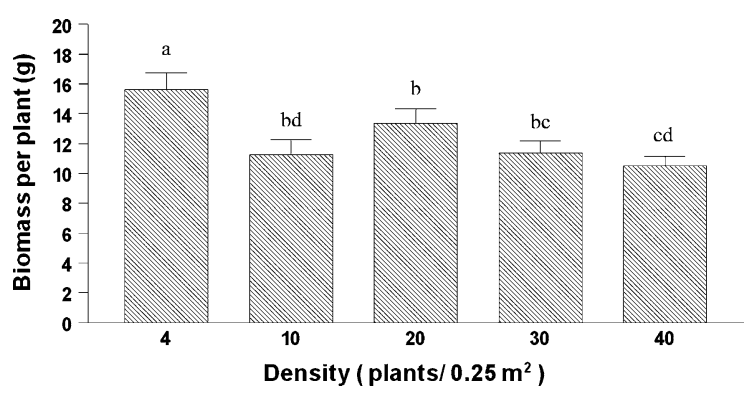

Fig. 4 Average biomass of cottonwood seedlings (per plant) at different density treatments $(4,10,20,30$, and 40 plants/ $0.25 \mathrm{~m}^{2}$ ) as a result of intraspecific competition at Bosque del Apache National Wildlife Refuge, New Mexico, 2002. Means followed by different lowercase letters indicate differences $(P<0.1)$ among treatments. Error bars represent standard error

$\mathrm{SE}=1.14)$ at 4 plants $/ 0.25 \mathrm{~m}^{2}$ (Fig. 4). Overall, seedling survival differed $\left(\chi_{4}^{2}=28.41, P<0.001\right)$ among treatments (Fig. 5). Survival of seedlings did not differ between densities of 4 plants and 10 plants $/ 0.25 \mathrm{~m}^{2}$. However, seedling survival at density of 20 plants $/ 0.25 \mathrm{~m}^{2}$ was the lowest among all treatments.

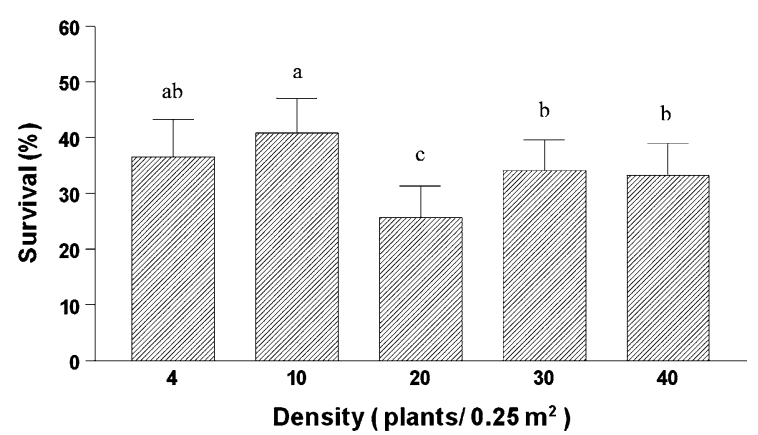

Fig. 5 Percent survival of cottonwood seedlings at different density treatments $\left(4,10,20,30\right.$, and 40 plants $\left./ 0.25 \mathrm{~m}^{2}\right)$ at Bosque del Apache National Wildlife Refuge, New Mexico, 2002. Means followed by different lowercase letters indicate differences $(P<0.1)$ among treatments. Error bars represent standard error

\section{Discussion}

In restored riparian areas, cottonwood seedlings can outcompete saltcedar seedlings in terms of biomass and height when natural hydrologic conditions are returned to a floodplain. The present state of saltcedar infestation in most river floodplains in the southwest 
US is not due to superior competitive ability of saltcedars, but, altered floodplain hydrology, leading to unfavorable recruitment conditions for native cottonwoods. Cottonwoods evolved with the annual flooding cycles of the rivers and the absence of such events has led to altered riparian dominance. Because cottonwood seeds are liberated for only a few weeks each year, absence of annual floods in the recent past have resulted in little to no regeneration of cottonwood. Saltcedar liberates seeds for about 6 months and their seeds are viable for longer than that of cottonwood. Thus, saltcedar seeds may germinate following any precipitation event occurring during the growing season (Horton et al. 1960).

Competitive ability of native cottonwoods against invasive saltcedars

Overall, height and biomass of cottonwoods and saltcedars decreased as total stem density increased. Taylor et al. (2006) also reported height of saltcedar and cottonwood to be negatively associated with higher combined stem densities. Increased numbers of cottonwood seedlings resulted in lower saltcedar biomass (Fig. 3). Also, a higher ratio of cottonwood to saltcedar (15:25) in the treatments, reduced height of saltcedar seedlings. The predictive models for biomass and height suggests a greater influence of cottonwood seedling densities than saltcedar. Therefore, if historical riparian hydrological patterns are restored, cottonwood seedlings, being the superior competitor, will reclaim areas where cottonwoods once were the dominant canopy species (Taylor et al. 2006).

Our study was the first documented experiment on seedling competition between the two species conducted in the natural floodplain conditions. However, despite the differences in predictive models developed in previous greenhouse experiments (Sher et al. 2000; Sher and Marshall 2003) and our study, combined results provide strong evidence that cottonwood are a superior competitor under cogerminating conditions. Further, a long-term study on cottonwoods and saltcedar (Taylor et al. 2006) has provided strong evidence of long-term competitive superiority of cottonwoods over.

Intraspecific competition

Intraspecific competition in cottonwood increased at higher densities leading to reduced biomass and survival compared to lower densities. Our results support findings by (Sprenger 1999, pp. 76-77), who reported that the relative growth rate of cottonwood seedlings was negatively affected by cottonwood density and concluded that cottonwood was affected more by increased intraspecific competition than by interspecific competition.

There was an optimum density (18-20 plants/plot) beyond which the height of cottonwood seedlings was reduced dramatically. Results of our study also support conclusions drawn from a long-term study by Taylor et al. (2006) suggesting initial high densities of cottonwood may lead to trees with lower DBH and hence low stand volume.

Restoration implications

Anthropogenic alterations of the Rio Grande have primarily led to creation of vast sites unsuitable for establishment and regeneration of native cottonwood in such areas. Saltcedar has been known to invade areas where young cottonwoods or other native vegetation are absent (Sher et al. 2000). To reestablish stands of cottonwoods, germination sites must be initially created mechanically by removing existing vegetation followed by artificial flooding (Taylor et al. 1999; Sprenger et al. 2002; Bhattacharjee et al. 2006). Several other restoration techniques such as planting of poles or seed-bearing branches along receding water levels in restoration sites following flooding have been reported to yield increased cottonwood recruitment. However, the literature unanimously agrees that the ultimate success of cottonwood restoration in the arid southwest US is only possible through the natural or simulated flood pulses that mimic historical hydrographs. While it is unreasonable to recommend the removal of dams from the rivers, it is advised for successful restoration of these riparia, that, flood pulses have to be simulated periodically and dams release water to cause overbank flows during early spring of "good water-years".

Acknowledgments We thank the management at Bosque del Apache National Wildlife Refuge for logistic support. Research was supported by the US Fish and Wildlife Service through the Bosque Improvement Group (through the efforts of Cyndie Abeyta), Caesar Kleberg Foundation for Wildlife Conservation, Turner Enterprises (through the efforts of Carter Kruse and Tom Wadell), and Texas Tech University. 
We appreciate help provided by the YCC crew (2002) and the fire crew at the Bosque del Apache National Wildlife Refuge for their help in fieldwork. We also thank Nancy McIntyre, Scott McMurry, and David Wester for their comments.

Open Access This article is distributed under the terms of the Creative Commons Attribution Noncommercial License which permits any noncommercial use, distribution, and reproduction in any medium, provided the original author(s) and source are credited.

\section{References}

Agresti A (1990) Categorical data analysis. Wiley, New York Attiwill PM (1994) The disturbance of forest ecosystems: the ecological basis for conservative management. For Ecol Manage 63:247-300. doi:10.1016/0378-1127(94)90114-7

Bhattacharjee J, Taylor JP Jr, Smith LM (2006) Controlled flooding and staged drawdown for restoration of native cottonwoods in the middle Rio Grande Valley, New Mexico. Wetlands 26:691-702. doi:10.1672/0277-5212 (2006)26[691:CFASDF]2.0.CO;2

Bhattacharjee J, Taylor JP Jr, Smith LM, Spence LE (2007) The importance of soil characteristics in determining survival of first year cottonwood seedlings in altered riparian habitats. Restor Ecol (in press)

Burnham KP, Anderson DR (2002) Model selection and multimodel inference-a practical information-theoretical approach, 2nd edn. Springer-Verlag, New York

Connell JH (1983) On the prevalence and relative importance of interspecific competition: evidence from field experiments. Am Nat 122:661-696. doi:10.1086/284165

Connolly J (1986) On difficulties with replacement-series methodology in mixture experiments. J Appl Ecol 23: 125-137. doi:10.2307/2403086

Connor EF, Simberloff D (1979) The assembly of species communities: chance or competition? Ecology 60:11321140. doi: $10.2307 / 1936961$

Crawford CS, Cully AC, Leutheuser R, Sifuentes MS, White LH, Wilber JP (1993) Middle Rio Grande ecosystem: Bosque biological management plan. United States Department of the Interior, Fish, and Wildlife Service, Albuquerque, New Mexico

deWit CT (1960) On competition. Versl Landbouwk Onderz Ned 66:1-82

Fairbank LG, Watkinson AR (1985) On the analysis of competition within two-species mixtures of plant. J Appl Ecol 22:503-517. doi:10.2307/2403181

Fenner P, Brady WW, Patton DR (1984) Observations on seeds and seedlings of Fremont cottonwood. Desert Plants 6: $55-58$

Friedman JM, Scott ML, Lewis WM (1995) Restoration of riparian forests using irrigation, artificial disturbance, and natural seedfall. Environ Manage 19:547-557. doi: 10.1007/BF02471966

Fule PZ, Covington WW, Moore MM (1997) Determining reference conditions for ecosystem management of southwestern ponderosa pine forests. Ecol Appl 7:
895-908. doi:10.1890/1051-0761(1997)007[0895:DRCF $\mathrm{EM}] 2.0 . \mathrm{CO} ; 2$

Gibson DJ, Connolly J, Hartnett DC, Weidenhamer JD (1999) Designs for greenhouse studies of interactions between plants. J Ecol 87:1-16. doi:10.1046/j.1365-2745.1999. 00321.x

Gilpin ME, Diamond JM (1984) Are species co-occurrences on islands non-random, and are null hypotheses useful in community ecology? In: Strong DR, Simberloff D, Abele LG, Thistle AB (eds) Ecological communities: conceptual issues and the evidence. Princeton University Press, Princeton, New Jersey, pp 297-315

Goldberg DE, Landa K (1991) Competitive effect and response: hierarchies and correlated traits in the early stages of competition. J Ecol 79:1013-1030. doi:10.2307/ 2261095

Goldberg DE, Werner PA (1983) Equivalence of competitors in plant communities: a null hypothesis and a field experimental approach. Am J Bot 70:1098-1104. doi: $10.2307 / 2442821$

Grime JP (1977) Evidence for the existence of three primary strategies in plants and its relevance to ecological and evolutionary theory. Am Nat 111:1169-1194. doi: $10.1086 / 283244$

Grime JP (2001) Plant strategies, vegetation processes, and ecosystem properties. Wiley, Chichester

Grumbine RE (1994) What is ecosystem management? Conserv Biol 8:27-38. doi:10.1046/j.1523-1739.1994.080 10027.x

Hobbs RJ, Norton DA (1996) Towards a conceptual framework for restoration ecology. Restor Ecol 4:93-110. doi: 10.1111/j.1526-100X.1996.tb00112.x

Horton JS, Mounts FC, Kraft JM (1960) Seed germination and seedling establishment of phreatophyte species. US Department of Agriculture, Rocky Mountain Forest and Range Experiment Station, Paper no. 48

Howe WH, Knopf FL (1991) On the imminent decline of Rio Grande cottonwoods in central New Mexico. Southwest Nat 36:218-224. doi:10.2307/3671924

Merkel DL, Hopkins HH (1957) Life history of salt cedar (Tamarix gallica L.). Transactions of the Kansas Academy of Science 60, Biological Sciences. Fort Hays Kansas State College, Hays, Kansas

Norrington-Davies J (1967) Applications of diallel analyses to experiments in plant competition. Euphytica 16:391-406. doi:10.1007/BF00028948

Pacala SW, Silander JA Jr (1985) Neighborhood models of plant population dynamics. I. Single-species models of annuals. Am Nat 125:385-411. doi:10.1086/284349

Pacala SW, Silander JA Jr (1990) Field tests of neighborhood population dynamic model of two weedy species. Ecol Monogr 60:113-134. doi:10.2307/1943028

Postel SL, Daily GC, Ehrlich PR (1996) Human appropriation of renewable fresh water. Science 271:785-788. doi: 10.1126/science. 271.5250 .785

Salo J, Kalliola R, Hakkinen I, Makinen Y, Niemela P, Puhakka $M$ et al (1986) River dynamics and the diversity of Amazon lowland forest. Nature 322:254-258. doi: $10.1038 / 322254 \mathrm{a} 0$

SAS/STAT user's guide (2001) Version 9.1, 4th edn. SAS Institute Inc., Cary 
Scheiner SM, Gurevitch J (eds) (2001) Design and analysis of ecological experiments, 2nd edn. Oxford University Press, New York

Schumm SA, Lichty RW (1963) Channel widening and floodplain construction along Cimarron River in southwestern Kansas: US Geological Survey Professional Paper 352-D. pp 71-88

Schutz WM, Brim CA (1967) Inter-genotypic competition in soybeans. I. Evaluation of effects and proposed field plot design. Crop Sci 7:371-376

Scott ML, Auble GT, Freidman JM (1997) Flood dependency of cottonwood establishment along the Missouri River, Montana, USA. Ecol Appl 7:677-690. doi:10.1890/10510761(1997)007[0677:FDOCEA]2.0.CO;2

Scott WH, Wondzell MA, Auble GT (1993) Hydrograph characteristics relevant to the establishment and growth of western riparian vegetation. In: Morel-Seytoux HJ (ed) Proceedings of the 13th Annual American Geophysical Union Hydrology Days. Hydrology Days Publications, Atherton, California, pp. 237-246

Segelquist CA, Scott ML, Auble GT (1993) Establishment of Populus deltoides under simulated alluvial ground water declines. Am Midl Nat 130:274-285. doi:10.2307/2426127

Sher AA, Marshall DL (2003) Competition between native and exotic floodplain tree species across water regimes and soil textures. Am J Bot 90:413-423. doi:10.3732/ajb.90.3.413

Sher AA, Marshall DL, Gilbert SA (2000) Competition between native Populus deltoides and invasive Tamarix ramosissima and the implications for reestablishing flooding disturbance. Conserv Biol 14:1744-1754. doi: 10.1046/j.1523-1739.2000.99306.x

Shinozaki K, Kira T (1956) Intraspecific competition among higher plants VII. Logistic theory of the C-D effect. J Inst Polytech, Osaka City University Series D Biol 7:35-72

Silvertown J, Charlesworth D (2001) Introduction to plant population biology. Blackwell Science, Oxford

Sprenger MD (1999) Restoration of riparian wildlife habitat in the middle Rio Grande Valley following historical river hydrographs. M.S. Thesis, Texas Tech University, Lubbock, Texas

Sprenger MD, Smith LM, Taylor JP (2002) Restoration of riparian habitat using experimental flooding. Wetlands 22:49-57. doi:10.1672/0277-5212(2002)022[0049:ROR HUE]2.0.CO;2

Stoll P, Weiner J (2000) A neighborhood view of interactions among individual plants. In: Deikmann U, Law R, Metz JAJ (eds) The geometry of ecological interactions-simplifying spatial complexity. Cambridge University Press, Cambridge

Stromberg JC (1997) Growth and survivorship of Fremont cottonwood, Gooding willow, and saltcedar seedlings after large floods in central Arizona. Great Basin Nat 57:198-208

Stromberg JC, Patten DT, Richter BD (1991) Flood flows and dynamics of Sonoran riparian forests. Rivers 2:221-235

Stromberg JC, Fry J, Patten DT (1997) Marsh development after large floods in an alluvial, arid-land river. Wetlands 17:292-300

Taylor JP, Wester DB, Smith LM (1999) Soil disturbance, flood management, and riparian woody plant establishment in the Rio Grande floodplain. Wetlands 19:372-382

Taylor JP, Smith LM, Haukos DA (2006) Evaluation of woody plant restoration in the middle Rio Grande: ten years after. Wetlands 26:1151-1160. doi:10.1672/0277-5212(2006)26 [1151:EOWPRI]2.0.CO;2

Tilman D (1982) Resource competition and community structure. Princeton University Press, Princeton

Tilman D (1988) Plant strategies and the dynamics and structure of plant communities. Princeton University Press, Princeton

Tyler CM, D'Antonio CM (1995) The effects of neighbors on the growth and survival of shrub seedlings following fire. Oecologia 102:255-264. doi:10.1007/BF00333258 